\title{
TOMAsz PALMirski
}

Uniwersytet Jagielloński

\section{'SOCIETAS LEONINA' W POGLĄDACH ANTONIO GOMEZA ORAZ DAVIDA MEVIUSA I ICH ODBICIE WE WSPÓŁCZESNYM FRANCUSKIM PRAWIE CYWILNYM}

Na gruncie prawa rzymskiego societas był to kontrakt zawierany pomiędzy przynajmniej dwiema osobami w celu podziału osiąganych przez spółkę zysków i strat, które ona przynosiła. Jeśli udziały w spółce nie zostały określone, były one równe. Natomiast, gdy miało miejsce umowne uregulowanie tej kwestii, granicę swobody stron stanowił przypadek, w którym jeden wspólnik ponosił tylko straty, nie otrzymując żadnych zysków. Tego typu spółka nazywana była lwią spółką (societas leonina) i była ona nieważna ${ }^{1}$.

1 D. 17,2,29,2 (Ulp. 30 ad Sab.): "Aristo refert Cassium respondisse societatem talem coiri non posse, ut alter lucrum tantum, alter damnum sentiret, et hanc societatem leoninam solitum appelare: et nos consentimus talem societatem nullam esse, ut alter lucrum sentiret, alter vero nullum lucrum, sed damnum sentiret: iniquissimum enim genus societatis est, ex qua quis damnum, non etiam lucrum spectet”. Na temat lwiej spółki zob. m.in. R. SoHм, Institutionen. Geschichte und System des römischen Privatrechts $^{17}$ (opr. L. Mitteis, L. Wenger), München-Leipzig 1923, s. 435; A. Steier, s.v. Löwe, «RE»13/1926, szp. 985; A. MAnIGK, s.v. 'Societas', «RE» 3/1927, szp. 774; V. Arangio-Ruiz, La Società in diritto Romano, Napoli 1950, s. 110; Idem, Istituzioni di diritto romano ${ }^{14}$, Napoli 1960, s. 349; F. Schulz, Classical Roman Law, Oxford 1951, s. 551; E. BetTi, Istituzioni di diritto romano, II.1, Padova 1960, s. 271, przyp. 67; M. KASER, Das römische Privatrecht, I: Das altrömische, das vorklassische und klassische Recht ${ }^{2}$, München 1971, s. 574; A. GuARINo, La società col Leone, «Labeo»18/1972, s. 72; IDEm, Diritto privato romano ${ }^{10}$, Napoli 1994, s. 932; A. PoggI, Il contratto di società in diritto romano classico, Roma 1972, s. 165-166; H. HAUSMANINGER, W. SELB, Römisches 
Odnośną problematykę podjęli również przedstawiciele, powstałej w XI w. w Bolonii, szkoły glosatorów. Zajmowali się oni przede wszystkim objaśnianiem występujących we wspomnianym fragmencie Digestów terminów lucrum i damnum, istotnych dla ewentualnego przyjęcia istnienia lwiej spółki. Z przeglądu znanych nam glos wynika, że glosatorowie akceptują w zasadzie bez ograniczeń, wzorem prawa justyniańskiego, nieważność tego typu umowy².

Podobnie przedstawiciele, powstałej w drugiej połowie XIII stulecia w Italii, szkoły komentatorów (konsyliatorów), przy czym widoczny jest brak głębszej refleksji $\mathrm{z}$ ich strony na tym polu³. Także prawnicy

Privatrecht ${ }^{4}$, Wien-Köln 1987, s. 308; P. Jörs, W. Kunkel, L. WEnger, Römisches Recht ${ }^{4}$ (opr. H. Honsell, Th. Mayer-Maly, W. Selb), Berlin-Heidelberg-New York 1987, $\$ 122$ III.3, s. 333; M. TAlamancA, Società in generale: Diritto romano, «ED»42/1990, s. 835; R. Zimmermann, The Law of Obligations: Roman Fundations of the Civilian Tradition, Cape Town-Wetton-Johannesburg 1990, s. 459; A. WACKE, Plaudereien über den Löwen und seine Gesellschaft, «Rechtshistorisches Journal» 10/1991, s. 136; H. Honsell, Römisches Recht ${ }^{2}$, Berlin-Heidelberg-New York 1992, s. 136; J. Garcia GonzÁlez, Sociedad leonina, [w:] Homenaje al profesor García-Gallo, III, Madrid 1996, s. 285 i n.; A. BüRGE, Römisches Privatrecht. Rechtsdenken und gesellschaftliche Verankerung. Eine Einführung, Darmstadt 1999, s. 100; K.-M. Hingst, Die 'societas leonina' in der europäischen Privatrechtsgeschichte, Berlin 2003, s. 35-127; W. LITEwsKI, Rzymskie prawo prywatne 5 , Warszawa 2003, s. 294; W. WoŁodKIEWICZ, M. ZABŁockA, Prawo rzymskie. Instytucje ${ }^{4}$, Warszawa 2005, s. 232; J.M. BLANCH NouguÉs, Reflexiones acerca de la 'societas leonina' en el Derecho Romano, «RIDA»55/2008, s. 83 i n.

2 Prób reinterpretacji norm rzymskich jest niewiele. Taką jest przede wszystkim próba odpowiedzi na pytanie, czy posiadacz lwich udziałów może obejść skutek nieważności societas leonina przez to, że swojemu wspólnikowi przyzna wyłącznie minimalny udział w zysku w formie nummus unus. Zob. K.-M. Hingst, op. cit., s. 129142; T. PAlmirski, 'Societas leonina' w twórczości glosatorów, [w:] 'Regnare, Gubernare, Administrare’. Z dziejów administracji, sądownictwa i nauki prawa. Prace dedykowane Profesorowi Jerzemu Malcowi z okazji 40-lecia pracy naukowej, red. S. GrodzISKI, A. Dziadzio, Kraków 2012, s. 181-189.

3 Być może taki stan rzeczy wynikał z przyjęcia przez komentatorów - wzorem prawa rzymskiego - braterskiej natury spółki, co jednoznacznie wykluczało jakiekolwiek próby obejścia zakazu posiadania lwich udziałów przez któregokolwiek ze wspólników. Zob. K.-M. Hingst, op. cit. s. 142-147; T. Palmirski, The 'Societas leonina' in the Work of Commentators, «Zeszyty Prawnicze» 18.4/2018, s. 247-258. 
działający w następnych stuleciach nie kwestionują nieważności tego typu spółki ${ }^{4}$.

Wyłomu w takim ugruntowanym postrzeganiu societas leonina dokonali dopiero żyjący w XVI w. Antonio Gomez oraz sto lat później jeden z przedstawicieli nowego kierunku badań nad prawem rzymskim - usus modernus pandectarum - David Mevius. Ich poglądy znalazły również odbicie w obecnie obowiązującym kodeksie cywilnym we Francji po jego zmianach dokonanych w 1978 r. I tej właśnie problematyce poświęcony będzie niniejszy artykuł.

Hiszpański prawnik i ksiądz Antonio Gomez ${ }^{5}$ w swoim komentarzu do prawa cywilnego stwierdza, że takie pactum, zgodnie z którym jeden ze wspólników otrzymuje część zysku, a drugi ponosi wszelkie straty, jest nieważne. Odwołuje się przy tym do D. 17,2,29,2, co może wskazywać na lwią spółkę, chociaż zauważyć należy, że skoro jeden ze wspólników otrzymuje część zysku, to ten, który partycypuje w całej stracie, nie jest wyraźnie wyłączony od jakiegokolwiek udziału w zysku' ${ }^{6}$. A takie wyłączenie, jak wiadomo, jest cechą charakterystyczną societas leonina, o której mowa we wspomnianym fragmencie Digestów? Być może zatem

\footnotetext{
4 Zauważyć jednak należy, że w pewnych przypadkach rozszerzają oni nawet zakres stosowania tej instytucji. Societas leonina kojarzyła się bowiem wówczas przede wszystkim z umowami, które chronią wspólnika wnoszącego kapitał do spółki przed stratami poprzez przyznanie mu na przykład stałej kwoty tytułem zysku. I chociaż w tak skonstruowanej umowie żaden ze wspólników nie jest od początku wykluczony od udziału w zysku, to jednak w takich przypadkach zakłada się istnienie lwiej spółki. Zob. K.-M. Hingst, op. cit., s. 147-169.

Na jego temat zob. Juristen. Ein biographisches Lexikon. Von der Antike bis zum 20. Jahrhundert, red. M. STOLLEIS, München 1995, s. 244.

6 quod non valet pactum, ut unus socius habeat partem lucri: alter vero totum damnum. tex. est in l. si non fueri $<n>t$. $\$$ Aristo. ff. pro socio. Antonius Gomezius, Commentariorum, variarumque resolutionum iuris civilis, communis et regis, Tomus secundus, Francofurti 1616, De Societate, Caput quintum, s. 267, przyp. 5.

7 Zob. przyp. 1.
} 
za nieważną lwią spółkę Gomez uznaje także spółkę określaną w nauce jako societas nummo uno. Pamiętać wszakże należy, że takie rozszerzenie pojęcia societas leonina (jako societas nummo uno) ${ }^{8}$ nie znajduje punktu zaczepienia w żadnym z trzech zdań zawartych w D. 17,2,29,2 i dlatego musi zostać odrzucone na gruncie prawa klasycznego (a także prawa justyniańskiego) ${ }^{9}$.

8 Taką możliwość na gruncie prawa rzymskiego przyjmują jedynie Antonio Guarino oraz Alfons Bürge. Pierwszy ze wspomnianych romanistów, w jednej ze swoich prac stwierdza bowiem, że lwia spółka ma miejsce także wtedy, gdy udział w zysku jednego wspólnika znajduje się w wyraźnej dysproporcji do jego udziału w stracie lub świadczonych wkładów (A. Guarino, op. cit., s. 932). A zatem, udział (nawet niewielki) w zysku nie wyklucza jeszcze przyjęcia nieważnej societas leonina. Z kolei Alfons Bürge za lwią spółkę przyjmuje również taką, w której udział w zysku jednego wspólnika skłania się do zera, on jednak mimo to - częściowo lub w całości - partycypuje w stracie (A. BürgE, op. cit., s. 100).

9 Klasyczne prawo rzymskie nie zajmowało się bezpośrednio problemem ważności tego rodzaju umowy. Źródła wspominają bowiem jedynie o nieważności umowy najmu rzeczy za jedną monetę i traktowaniu jej odpowiednio jako darowizny (D. 19,2,46) albo precarium (D. 41,2,10,2). Zob. też M. KAsER, op. cit., s. 243 i przyp. 5. Wydaje się, że zasada ta może być stosowana per analogiam również w przypadku innych kontraktów konsensualnych, np. kupna-sprzedaży (tutaj brak spełnienia wymogu pretium verum). Zob. R. Zimmermann, op. cit., s. 252 i przyp. 115. Jeżeli chodzi natomiast o societas nummo uno, to jak się wydaje, możliwe są tutaj dwa rozwiązania. Po pierwsze, kierując się zasadą wspomnianą powyżej, można by przyjąć nieważność tego typu umowy (zob. R. ZimMERMANN, op. cit., s. 459, przyp. 56). Z drugiej strony, tak jak próbował to wyjaśniać anonimowy glosator (zob. niżej przyp. 5), chcąc utrzymać w mocy societas nummo uno, należałoby, uznawszy ważność tego typu spółki, pozostawić sędziemu określenie na nowo proporcji pomiędzy udziałami tworzących ją wspólników w przypadku, gdyby doszło między nimi na tym tle do sporu. 


\section{Kwestia symbolicznego udziału w zysku pojawiła się bowiem po raz pierwszy dopiero u glosatorów ${ }^{10}$.}

10 Odnośne rozważania zawarte są jedynie w anonimowej glosie do zdania drugiego D. 17,2,29,2, i odnoszą się one do sposobu, w jaki wspólnik posiadający „lwi udział” mógłby uniknąć nieważności societas leonina. Glosator odwołuje się do D. 17,2,29 pr., gdzie mowa o tym, że możliwa jest taka spółka, w której wspólnicy mają różne udziały w zyskach i stratach. Pyta, gdzie zatem jest granica tej dysproporcji, która jeszcze nie prowadzi do uznania spółki za lwią spółkę. Według glosatora jest nią chociażby najmniejszy zysk (jedna moneta) i to nawet wtedy, gdy wspólnik, który go otrzymuje, ponosi wszystkie straty (Sed cum maiorem partem lucri, \& minorem damni ex pacto possunt percipere: ut supra ead. 1. in princip. quis erit finis? videtur enim quod si etiam unum nummum pro lucro habeat, \& totum damnum: quod valeat. Corpus Iuris Civilis Iustinianei, cum commentariis Accursii, scholiis Contii, et D. Gothofredi lucubrationibus ad Accursium, in quibus Glossae obscuriores explicantur, similes \& contrariae afferuntur, vitiosae notantur. Accesserunt Iacobi Cuiacii Paratitla in Pandectas \& Codicem, Studio et opera Ioannis Fehi, Tomus hic Primus Digestum Vetum continent, Lugduni 1627, przedruk Osnabrück 1965 [cyt. dalej Fehius I], szp. 1664, „q”). I chociaż uznaje taką umowę za dopuszczalną, to zarazem problematyczną. Taka bowiem umowa, w której jeden ze wspólników otrzymuje jako zysk jedną monetę, z ekonomicznego punktu widzenia różni się od societas leonina jedynie dogmatycznie. Rozwiązaniem tego problemu miałoby być ustalenie przez sędziego minimalnej proporcji pomiędzy różnymi udziałami wspólników. Formułując powyższą opinię, glosator odnosi się przy tym do D. 17,2,6, gdzie mowa jest, że w przypadku, gdy to jeden ze wspólników miał określić udziały swoje i drugiego wspólnika, musiał to uczynić zgodnie z osądem uczciwego człowieka - arbitrium boni viri (Sed respon. arbitrio iudicis hoc dirimendum ut arg. s. eod. 1. si societatem. 2. Vel verius hoc valet usque ad tres partes non ultra. nam sic figit haec lex suos pedes: ut in princi. sui dicit. Fehius I, szp. 1664, „q”). Na gruncie prawa rzymskiego bowiem sędzia rozpoznający sprawę zainicjowaną skargą z kontraktu spółki (actio pro socio), tak jak i przy innych skargach dobrej wiary (iudicia bonae fidei), miał pełną swobodę przy miarkowaniu zasądzenia. Tak więc mógł on przyznać „lwiemu wspólnikowi” tylko część jego olbrzymiej, sprzecznej z dobrą wiarą kwoty zysku, zaś gdyby powodem był drugi ze wspólników, więcej niż tylko jedną, należną mu z tytułu umowy spółki, monetę (zob. D. 17,2,6; zob. też W. LiteWski, Rzymskie..., s. 255). W zdaniu drugim stwierdza jednak, że „bardziej słuszna” (verius) od całkowitej dowolności w tym względzie wydaje się mu granica trzech części, o której mowa w prawie (czyli w D. 17,2,29 pr.). Sens tej wypowiedzi nie jest całkiem jasny. Mogłoby to oznaczać, że „lwiemu wspólnikowi” mogą przysługiwać maksymalnie tres partes (z czterech), a więc 3/4 zysku, to znaczy, że owa symboliczna moneta, którą otrzyma drugi wspólnik, musi mieć minimalną wartość $1 / 4$ zysku. Jeśli jest mniej warta, umowa spółki jest nieważna. Takie rozumowanie nie wydaje się jednak do końca uzasadnione. Ułamki, o których 
Godne uwagi jest natomiast to, jakie skutki prawne przewiduje Gomez dla zawartej na takich zasadach spółki. Stwierdza on bowiem, że nie cała spółka jest nieważna, lecz jedynie owo pactum określające udziały wspólników w spółce ${ }^{11}$. Wydaje się, że powyższe rozdzielenie umowy spółki od dołączanego do niej nieformalnego porozumienia (pactum) - tutaj mającego za przedmiot określenie udziałów w spółce - rozumieć można jako nawiązanie do abstrakcyjnego pytania postawionego już przez Azona: „quod pactum apponi possit in societate contrahenda” ${ }^{2}$. Niemniej pamiętać należy, że wspomniany wyżej glosator w jego słynnych

mowa w D. 17,2,29 pr., traktować bowiem należy jedynie jako przykładowe, a nie jako prawną granicę swobody w kształtowaniu stosunku umownego. W innym bowiem fragmencie tytułu drugiego, siedemnastej księgi Digestów (chociaż w nieco innym kontekście) mowa jest bowiem o tym, że należy przyjąć za uczciwe ustalenie udziałów w wysokości odpowiednio 1/1000 dla jednego ze wspólników i 999/1000 dla drugiego, zwłaszcza gdy jeden z nich wniósł do spółki więcej pracy, trudu, starań czy pieniędzy (zob. D. 17,2,80; co do problematyki związanej z pozostawieniem oznaczenia świadczenia osobie trzeciej zob. M. KASER, op. cit., s. 490 i tam cytowana literatura). Zważyć jeszcze należy, że odwołanie się przez glosatora w swych rozważaniach do D. 17,2,29 pr. jest błędne. We wspomnianym fragmencie Digestów nie mówi się bowiem o tym, że dopuszczalna jest sytuacja różnych udziałów w zyskach i stratach tego samego wspólnika, lecz że mogą być one różne jedynie w relacji między wspólnikami, ale takie same w relacji zysk-strata. Wydaje się zatem, że lepszym punktem odniesienia dla rozważań o societas nummo uno byłyby fragmenty zawarte w D. 17,2,30 (a także w I. 3,25,2 oraz G. 3,149). Na temat tych dwóch ostatnich tekstów zob. J.M. BlanCH Nougués, op. cit., s. 92-106 i przyp. 37; Z. Benincasa, Kontrakt spółki jako alternatywna dla pożyczki morskiej forma prawna finansowania handlu morskiego, «Zeszyty Prawnicze»10.2/2010, s. 71-86. Abstrahując od wspomnianych wyżej niejasności zawartych w komentarzu anonimowego glosatora, wskazuje on słusznie na ważny problem związany z możliwością omijania zakazu formowania spółki jako lwiej, poprzez tzw. societas nummo uno.

11 Non tamen intelligas, quod societas sit nulla, sed quod pactum inaequale vitietur, \& ipso iure annulletur. Antonius Gomezius, op. cit., s. 267, przyp. 5. Gomez reprezentuje przez to zupełnie nową, przyszłościową ideę odchodzącą od rozwiązania prawa rzymskiego, które w przypadku ustalenia lwich udziałów w umowie spółki, uznawało ją za nieważną.

12 Summa Azonis locuples iuris civilis thesaurus, Venetia 1566, s. 1109. 
Summa in Codicem ${ }^{13}$ stwierdza, że jeśli jednak przy zawieraniu spółki zostanie uzgodnione, iż jeden ponosi całą stratę, a drugi otrzymuje cały zysk, taka spółka nie może trwać, ponieważ jest to spółka lwia, opisana w bajkach Ezopa ${ }^{14}$.

Hiszpański jurysta postępuje zatem zgodnie z zasadą utile per inutile non vitiatur ${ }^{15}$. Nie mówi natomiast, jaki podział powinien mieć zastosowanie w miejsce nieważnego pactum. Wydaje się jednak, że w takim przypadku, skoro udziały w spółce nie są określone, winny być one równe, stosownie do opinii Ulpianusa zawartej w D. 17,2,29 pr.

Ów nowatorski pogląd, zgodnie z którym nie cała umowa (lwiej) spółki miałaby być nieważna, lecz tylko porozumienie (pactum) odnośnie do lwich udziałów, został zakwestionowany przez Oswalda Hilligera (1583-1619) ${ }^{16}$, jednego z przedstawicieli niemieckich prawników-humanistów. W swoim opracowaniu głównego dzieła Hugona Donellusa ${ }^{17}$ zatytułowanego Commentarii de jure civili, podobnie jak wspomniany

13 Między rokiem 1482 a 1610 ukazało się aż 35 wydań tego dzieła. Zob. M. STOLLEIS, op. cit., s. 53; zob. też F. WIEACKER, Privatrechtsgeschichte der Neuzeit unter besonderer Berücksichtigung der deutschen Entwicklung ${ }^{2}$, Göttingen 1967, s. 63.

$14 \mathrm{Si}$ autem in societate contrahenda fiat pactum, ut unus totum damnum subeat, alter vero totum lucrum habeat, non tenet societas: quia leonina est, ut in fabulis Aesopi continetur (Summa Azonis locuples iuris civilis thesaurus, s. 398). O utworach Ezopa i innych autorów, w których pojawia się motyw lwiej spółki, zob. K.-M. Hingst, op. cit., s. 42-48; B. Møller Jensen, 'Societas leonina' or the lion's share. An analysis of 'Aesopica' 149, Phaedrus I.5 and Babrius I.67, http.hprints.org/hprints-004-75199 (dostęp 14 grudnia 2020 r.).

15 Na temat tej zasady zob. D. LIEBs, Lateinische Rechtsregeln und Rechtssprichwörter ${ }^{4}$, München 1986, s. 216; M. Kaser, op. cit., s. 247 i przyp. 10; H.H. Seiler, 'Utile per inutile non vitiatur'. Zur Teilungwirksamkeit von Rechtsgeschäften im römischen Recht, [w:] Festschrift für Max Kaser zum 70. Geburstag, red. D. Medicus, H.H. SEILER, München 1976, s. 127-147.

16 R. Wirth, Oswald Hilliger - ein Jenaer Professorenleben, «Mitteilungen des Freiberger Altertumsvereins» 77/1996, s. 65-81.

17 Żyjący w latach 1527-1591 Hugo Donellus (Hugo Doneau) był jednym z przedstawicieli tzw. francuskiej eleganckiej jurysprudencji. Na jego temat zob. przede wszystkim F. WiEACKer, op. cit., s. 167; Juristen. Ein biographisches Lexikon..., s. 175-177; H. SCHLOSSER, op. cit., s. 45. 
jurysta - który tego typu umowę uważa za nieważną w całości ${ }^{18}$ - sprzeciwia się utrzymaniu takiej spółki ${ }^{19}$.

Dokonanie rozgraniczenia pomiędzy nieformalnym pactum, ustalającym udział wspólników w zyskach i stratach generowanych przez spółkę, oraz samą umową spółki postulował również, żyjący w latach 1609-1670 David Mevius ${ }^{20}$, jeden z najbardziej znaczących przedstawicieli nowego kierunku badań nad prawem rzymskim, który pojawił się na początku XVII w. w Niemczech - usus modernus pandectarum ${ }^{21}$. W swoim dziele zatytułowanym Commentarius in Jus Lubecense stwierdził on bowiem między innymi, powołując się na fragment dzieła wspomnianego wyżej

18 Hoc modo societatem contractam nullius esse momenti. H. Donellus, Opera Omnia, Commentariorum de iure civili, Tomus tertius, cum notis Osualdi Hilligeri accedunt summaria et castigations theologicae, Florentinae 1841, szp. 946; zob. też T. PALMIRSKI, 'Societas leonina' w poglądach francuskich przedstawicieli tak zwanej eleganckiej jurysprudencji, [w:] 'Semper fidelis'. Prace dedykowane pamięci Profesora Janusza Sondla, legendzie krakowskiego fakultetu prawniczego, red. D. MALEC, Ł. Marzec, T. PAlmirski, Kraków 2017, s. 289-295 (= «Miscelanea Historico-Iuridica» 17.2/2018, s. 175-188).

19 Male a<utem $>$ [...] Gomez [...] non contractum societ<atis $>$ nullum esse sed convent $<$ ionem $>$ solam adjectam vitiari, re ad aequalitatem reducta. Oswaldus Hiligerius, Donellus enucleatus sive commentarii Hugonis Donelli de jure civili in compendium ita redacti ut verum nucleum contineat, jurisque artem, quae amplo verborum cortice in illis tecta, apertius exhibeant, Jenae 1611, s. 1100, przyp. M (do s. 1097) = H. Donellus, op.cit., szp. 946 przyp. 12.

20 Na jego temat zob. przede wszystkim F. WIEACKER, op. cit., s. 218-235; R. vON StintzIng, Geschichte der deutschen Rechtswissenschaft, II: 2. Hälfte des 17. Jahrhunderts, München-Leipzig 1884 (przedruk Aalen 1978), s. 112-139; Juristen. Ein biographisches Lexikon..., s. 425.

${ }^{21}$ Charakteryzował się on nowoczesnym stosowaniem - utożsamianych z prawem rzymskim jako takim - Pandektów (Digestów justyniańskich), odpowiednim do czasów (mores hodierni) - a więc przy uwzględnieniu licznych w Niemczech praw partykularnych - ich wykorzystaniem w praktyce. Usus modernus swoją nazwę zawdzięcza tytułowi sławnego podręcznika autorstwa żyjącego w latach 1640-1710 Samuela Stryka, zatytułowanego Specimen usus moderni Pandectarum (trzy tomy wydane po raz pierwszy w latach 1690-1706). Zob. F. WieAcKer, op. cit., s. 204-248; Handbuch der Quellen und Literatur der neueren europäischen Privatrechtsgeschichte, II: Neuere Zeit (1500-1800). Das Zeitalter des gemeinen Rechts, 1: Wissenschaft, red. H. CoING, München 1976, s. 501-614. 
Antonio Gomeza ${ }^{22}$, że nadmierna nierówność zastrzeżona w nieformalnym pactum powoduje tylko jego nieważność, nie zaś całej umowy spółki, co ma na przykład miejsce, gdy zostało uzgodnione, że jeden wspólnik otrzymuje (cały) zysk, drugi zaś ponosi straty bez udziału w zysku ${ }^{23}$. Powstaje zatem pytanie, w jaki sposób, po unieważnieniu pactum zawierającego odnośne postanowienia, ustalić na nowo udziały wspólników. Wydaje się, że należy postąpić tak, jak w przypadku, w którym od początku brak umownego uregulowania tej kwestii, a zatem dokonać podziału zysków i strat po równo tak, jak jest o tym mowa w D. 17,2,29 pr. $^{24}$, o ile nie skłaniają do innego podziału różne wkłady wniesione przez wspólników do spółki ${ }^{25}$.

Instytucja lwiej spółki, wzorowana na rzymskiej societas leonina, nie była również obca francuskiemu prawu cywilnemu. Jej systematyczne podstawy stworzyli działający w XVII w. Jean Domat oraz żyjący w następnym stuleciu Robert Josèphe Pothier ${ }^{26}$. Pierwszy ze wspomnianych spółkę, której postanowienia obrażają sprawiedliwość i dobrą wiarę - co

22 Zob. przyp. 6.

23 Nimia inaequalitas in societate vitiat pactum, non tamen ipsum contractum. David Mevius, Commentarii in Jus Lubecense libri quinque: ad explicationem ejusdem solidam [...], Francofurti ad Moenum 1679, Summaria 8., s. 703; Pactis [...] moderari licet, in quibus cavendum est, ne nimis alterum sociorum laedant, alium juvent. Unde injusta \& invalida haec habentur, ita tamen ut ipsa, non contractus ipse annulletur. Gomez d. cap. 5. n. 5. veluti cum convenit, ut alter lucrum, alter damnum sentiat sine lucro, quam societatem leoninam \& iniquissimum conventionis genus JCtus appellat [...]. Ibidem, s. 704.

24 In dubio si pactum nihil aliud dictum reperitur, nec partes societati adjectae sunt, pro partibus aequalibue ea contracta censetur, \& sic inter socios lucrum \& damnum dividitur 1. si non fuerint 29. pr. Ibidem, s. 704.

25 Quod si inaequales partes societatis sint, nec sors vel opera aequaliter conferatur, pro rata illae partis aut praestitae operae division fiet lucri \& damni. Aequalitas enim non Arithmetica sed Geometrica, prout unus vel alter sociorum plus minus opere \& pecuniae contulerit, hic attenditur. Ibidem, s. 704.

26 Na ich temat zob. przede wszystkim F. WIEACKER, op. cit., s. 211, 340-342, 377. 
ma miejsce wówczas, gdy jeden ze wspólników ponosił całą stratę, nie partycypując w zysku, zaś drugiemu, który nie miał udziału w stracie przypadał cały zysk - uznaje za nieważną. Przy czym Domat nie posługuje się w takim przypadku określeniem société leonine, lecz société frauduleuse ${ }^{27}$. Z kolei Pothier za lwią spółkę uważa taką, w której tylko jeden ze wspólników uczestniczyłby w zysku. Przy czym nie wymaga, aby drugi ze wspólników, który wyłączony jest od udziału w zysku, ponosił całą stratę. Tego typu spółka, jako spółka pozorna (une prétendue société) według wspomnianego autora, jest nieważna ${ }^{28}$.

Jeżeli zaś chodzi o odnośne regulacje zawarte w kodeksie cywilnym (Code civil des Français; w latach 1807-1814 zwanym Code Napoléon), pierwszej wielkiej kodyfikacji wydanej w 1804 r. po upadku ancien régime'u w wyniku rewolucji francuskiej ${ }^{29}$, to znajdują się one w art. $1855^{30}$. Według cytowanego przepisu nieważna jest umowa, w której całość zysków przyznana jest jednemu ze wspólników albo zwalniająca jednego lub kilku wspólników od udziału w stratach. Zważyć jednakże należy, że w literaturze francuskiej przez długi okres było kwestią sporną, czy wspomniany w tym przepisie skutek nieważności dotyczy

27 Toute societé oú il y auroit quelque conditio qui blesseroit l'équité \& la bonne foi, seroit illicite. Comme s'il étoit convenu que toute la perte seroit d'une part sans aucun profit, \& tout le profit de l'autre sans aucune perte. J. DomAT, Les loix civiles dans leur ordre naturel [...], nouvelle édition, I, Paris 1703, s. 90.

28 C'est pourquoi si, par le contrat d'une prétendue société, il était convenu, que le profit appartiendrait en entier à l'une des parties contractantes, sans que l'autre y pût prétendre de part en aucun cas, une telle convention ne serait pas un contrat de société, et elle serait nulle, comme manifestement injuste. Oeuvres de R.-J. Pothier, contenant les traités du droit français, nouvelle édition, red. M. Dupin AInÉ, II, Bruxelles 1831, s. 405 .

29 Na temat dziejów powstania Kodeksu Napoleona i dalszych jego reform zob. przede wszystkim K. SójKA-ZIELIŃsKa, Kodeks Napoleona. Historia i współczesność ${ }^{2}$, Warszawa 2008; IDEm, Wielkie kodyfikacje cywilne. Historia i współczesność, Warszawa 2009, s. 175-258; zob. też P. ŚwięCICKA-WystrychowsKa, Kodeks Napoleona a prawo rzymskie, «Kwartalnik Prawa Prywatnego» 13.4/2004, s. 1095-1132.

30 Art. 1855: (1) La convention qui donnerait à l'un des associés la totalité des bénéfices, est nulle. (2) Il en est de meme de la stipulation qui affranchirait de toute contribution aux pertes, les sommes ou effets mis dans le fonds de la société par un ou plusieurs des associés. 
tylko lwiej klauzuli (clause léonine), a nie całej umowy spółki (która istnieje nadal, a podział zysków i strat następuje w myśl art. 1853 - regulującego te kwestie w przypadku, gdy zawierające umowę spółki strony nic na ten temat nie uzgodniły - stosownie do wniesionych przez nie wkładów $\left.{ }^{31}\right)$, czy też cała umowa jest nieważna. Ostatecznie przeważył drugi ze wspomnianych wyżej poglądów i tak z biegiem czasu decydowały - w każdym razie od końca XIX w. - również francuskie sądy, zwłaszcza wtedy, gdy umieszczenie zapisów mających znamiona clause léonine było decydującym motywem zawarcia umowy spółki ${ }^{32}$.

Stan taki trwał do 1978 r., kiedy to w wyniku dokonanej wówczas nowelizacji code civil zmianie uległy, między innymi, przepisy dotyczące société civile. W tym także cytowany wyżej art. 1855, który został zastąpiony przez art. $1844-1^{33}$. Dla problematyki poruszanej w niniejszym ar-

$31 \quad$ Art. 1853: Lorsque l'acte de société ne determine point la part de chaque associé dans les bénéfices ou pertes, la part de chacun est en proportion de sa mise dans le fonds de la société.

32 Za całkowitą nieważnością lwiej spółki przemawia, po pierwsze, analogia do normy zawartej w art. 1172, zgodnie z którą umowa zawierająca w swej treści warunek niedozwolony jest nieważna. Po drugie, pogląd przeciwny zakładający nieważność jedynie lwiej klauzuli i wprowadzenie w jej miejsce regulacji, o której mowa w art. 1853, nie do końca da się utrzymać, ponieważ jest co najmniej wątpliwe, czy ten pierwotnie uprzywilejowany wspólnik zawarłby w ogóle umowę spółki, w której udziały w zyskach i stratach określane są stosownie do wniesionych przez wspólników wkładów. I w końcu, po trzecie, również przebieg prac nad kodeksem i prezentowane wówczas stanowiska mające swe uzasadnienie w przedstawionych wyżej poglądach doktryny przemawiają za całkowitą nieważnościąlwiej spółki. Wyjątek stanowi jedynie przypadek, gdy lwia klauzula została dodana do umowy spółki dopiero po jej zawarciu. Zob. A. WACKE, op. cit., s. 137; G. Ripert, J. Boulanger, Traité de Droit Civil d'apres le Traité de Planiol, III: Suretés réelles. Publicité fonciéere, Contrats civils. Principaux Contrats, Paris 1958, s. 728, przyp. 2214; J. Lepargneur, Société et Association, [w:] Traité Pratique de Droit Civil Français, red. M. Planiol, G. Ripert, XI: Contrats civils ${ }^{2}$, Paris 1954, s. 318-320; CH. Müller-Gugenberger, Bemerkungen zur 'societas leonina'. Fabel-haftes im Gesellschaftsrecht, [w:] Gesetzgebungstheorie, Juristische Logik, Zivil- und Prozeßrecht. Gedächtnisschrift für Jürgen Rödig, red. U. KLUG, Berlin-Heidelberg-New York 1978, s. 275.

33 Art. 1844-1: (1) La part de chaque associé dans les bénéfices et sa contribution aux pertes se déterminent à proportion de sa part dans le capital social et la part de l'associé qui n'a apporté que son industrie est égale à celle de l'associé qui a le moins apporté, le tout sauf clause contraire. (2) Toutefois, la stipulation attribuant à un associé 
tykule szczególnie istotna jest treść zdania drugiego. Tamże jest bowiem mowa o tym, że klauzula umowy spółki, w której przyznaje się jednemu wspólnikowi cały zysk wypracowany przez spółkę lub zwalnia się go z ponoszenia wszelkich strat, jak też klauzula wyłączająca wspólnika od partycypacji w zysku albo obciążająca go wszelkimi stratami, uważana jest za niezapisaną (réputée non écrite), to znaczy za niewywołującą żadnych skutków prawnych ${ }^{34}$. A zatem nie cała umowa jest nieważna (tak jak na gruncie art. 1855 z 1804 r.), lecz jedynie owa clause léonine ${ }^{35}$.

Widać zatem wyraźnie, że dokonanie rozgraniczenia pomiędzy nieformalnym pactum, ustalającym udział wspólników w zyskach i stratach generowanych przez spółkę, oraz samą umową spółki postulowane przez Antonio Gomeza, a następnie przez Davida Meviusa, które stanowiło istotny wyłom w ówczesnym postrzeganiu lwiej spółki, znalazło swój refleks we współczesnym francuskim prawie cywilnym. Można również pokusić się o stwierdzenie, że odnośne regulacje Kodeksu Napoleona przeszły podobną transformację (od przyjęcia nieważności całej umowy spółki do nieważności jedynie tych jej zapisów, które określano mianem clause léonine).

Z oczywistych względów nie można tutaj mówić o jakiejkolwiek recepcji. Nie sposób bowiem udowodnić, by dokonując w 1978 r. nowelizacji code civil, korzystano z prac wspomnianych wyżej autorów.

la totalité du profit procuré par la société ou l'exonérant de la totalité des pertes, celle excluant un associé totalement du profit ou mettant à sa charge la totalité des pertes sont réputées non écrites.

34 Wówczas, podobnie jak to miało miejsce na gruncie obowiązującego poprzednio art. 1853, udział w zyskach i stratach każdego ze wspólników ustala się proporcjonalnie do jego udziału w kapitale zakładowym (zob. wyżej art. 1844-1 zd. pierwsze).

35 Na temat clause léonine pod rządami code civil po jego zmianach w 1978 r. zob. m.in. P. Merle, Droit commercial. Sociétés commerciales ${ }^{3}$, Paris 1992, s. 48-50, przyp. 41-46, s. 72, przyp. 68, s. 614, przyp. 656; M. Cozian, A. Viandier, Droit des sociétés, Paris 1994, s. 67-69, przyp. 189-191; G. Ripert, R. Roblot, M. René, Traité de droit commercial $^{16}$, Paris 1996, s. 538-541, przyp. 691-694, s. 694, przyp. 923, s. 822, przyp. 1133, s. 902, przyp. 1249. 


\section{'Societas leonina' w poglądach Antonio Gomeza ORAZ Davida MEVIUSA I ICH ODBICIE WE WSPÓŁCZESNYM FRANCUSKIM PRAWIE CYWILNYM}

\section{Streszczenie}

Na gruncie prawa rzymskiego spółka, w której jeden wspólnik ponosił tylko straty, nie otrzymując żadnych zysków, zwana była societas leonina i była ona nieważna. W podobnym tonie wypowiadali się również przedstawiciele, powstałej w XI w. w Bolonii, szkoły glosatorów, a także powstałej w drugiej połowie XIII stulecia w Italii szkoły komentatorów (konsyliatorów). Również prawnicy działający w następnych stuleciach nie kwestionują nieważności tego typu spółki. Wyłomu $\mathrm{w}$ takim ugruntowanym postrzeganiu societas leonina dokonali dopiero żyjący w XVI w. Antonio Gomez oraz sto lat później jeden z przedstawicieli nowego kierunku badań nad prawem rzymskim - usus modernus pandectarum - David Mevius. Ich poglądy znalazły również odbicie we współcześnie obowiązującym kodeksie cywilnym we Francji. I tej właśnie problematyce poświęcony będzie niniejszy artykuł.

The 'societas leonina' in the Views of Antonio Gomez And David Mevius and their Reflection in Contemporary French Civil LaW

\section{Summary}

In Roman law the societas leonina was a partnership in which one of the partners was only liable for loss and excluded from sharing in the profit. Such partnerships were regarded as null and void. The representatives of the school of Glossators, established in the $11^{\text {th }}$ century in Bologna and the Commentators established in the second half of the $13^{\text {th }}$ century in Italy also spoke in a similar tone. Lawyers operating in the following centuries did not question the nullity of this kind of partnership, either. It was not until the $16^{\text {th }}$ century that a major change came in this well-established perception of the societas leonina, and it 
was made by Antonio Gomez. A century later David Mevius, one of the representatives of the usus modernus pandectarum, concurred with Gomez' opinion. Their views are reflected in contemporary French civil law, and that is the the subject of this article.

Słowa kluczowe: prawo rzymskie; szkoła glosatorów; szkoła komentatorów (konsyliatorów); societas leonina; societas nummo uno; Antonio Gomez; David Mevius; usus modernus pandectarum; Jean Domat; Robert Josèphe Pothier; francuski kodeks cywilny.

Keywords: Roman law; the School of Glossators; the School of Commentators (Counsellors); the societas leonina; the societas nummo uno; Antonio Gomez; David Mevius; usus modernus pandectarum; Jean Domat; Robert Josèphe Pothier; the French civil code.

\section{Literatura}

Antonius Gomezius, Commentariorum, variarumque resolutionum iuris civilis, communis et regis, Tomus secundus, Francofurti 1616.

Arangio-Ruiz V., Istituzioni di diritto romano ${ }^{14}$, Napoli 1960.

Arangio-Ruiz V., La Società in diritto Romano, Napoli 1950.

Benincasa Z., Kontrakt spółki jako alternatywna dla pożyczki morskiej forma prawna finansowania handlu morskiego, «Zeszyty Prawnicze»10.2/2010, s. 71-86. BetTi E., Istituzioni di diritto romano, II.1, Padova 1960.

Blanch Nougués J.M., Reflexiones acerca de la 'societas leonina' en el Derecho Romano, «RIDA» 55/2008, s. 83-106.

BüRGE A., Römisches Privatrecht. Rechtsdenken und gesellschaftliche Verankerung.

Eine Einführung, Darmstadt 1999.

Corpus Iuris Civilis Iustinianei, cum commentariis Accursii, scholiis Contii, et

D. Gothofredi lucubrationibus ad Accursium, in quibus Glossae obscuriores explicantur, similes \& contrariae afferuntur, vitiosae notantur. Accesserunt Iacobi Cuiacii Paratitla in Pandectas \& Codicem, Studio et opera Ioannis Fehi, Tomus hic Primus Digestum Vetum continent, Lugduni 1627, przedruk Osnabrück 1965. Cozian M., Viandier A., Droit des sociétés ${ }^{7}$, Paris 1994.

David Mevius, Commentarii in Jus Lubecense libri quinque: ad explicationem ejusdem solidam [...], Francofurti ad Moenum 1679.

Garcia González J., Sociedad leonina, [w:] Homenaje al profesor García-Gallo, III, Madrid 1996, s. 285-294.

Guarino A., Diritto privato romano ${ }^{10}$, Napoli 1994. 
GuARino A., La società col Leone, «Labeo»18/1972, s. 72-77.

Handbuch der Quellen und Literatur der neueren europäischen Privatrechtsgeschichte, II: Neuere Zeit (1500-1800). Das Zeitalter des gemeinen Rechts, 1: Wissenschaft, red. H. CoIng, München 1976.

Hausmaninger H., Selb W., Römisches Privatrecht ${ }^{4}$, Wien-Köln 1987.

Hingst K.-M., Die 'societas leonina' in der europäischen Privatrechtsgeschichte, Berlin 2003.

Honsell H., Römisches Recht², Berlin-Heidelberg-New York 1992.

Hugo Donellus, Opera Omnia, Commentariorum de iure civili, Tomus tertius, cum notis Osualdi Hilligeri accedunt summaria et castigations theologicae, Florentinae 1841.

JeAn Domat, Les loix civiles dans leur ordre naturel [...], nouvelle édition, I, Paris 1703. Jörs P., Kunkel W., Wenger L., Römisches Recht ${ }^{4}$ (opr. H. Honsell, Th. Mayer-Maly, W. Selb), Berlin-Heidelberg-New York 1987.

Juristen. Ein biographisches Lexikon. Von der Antike bis zum 20. Jahrhundert, red. M. STOLleis, München 1995.

KAser M., Das römische Privatrecht, I: Das altrömische, das vorklassische und klassische Recht ${ }^{2}$, München 1971.

Lepargneur J., Société et Association, [w:] Traité Pratique de Droit Civil Français, red. M. Planiol, G. Ripert, XI: Contrats civils², Paris 1954.

LiEBs D., Lateinische Rechtsregeln und Rechtssprichwörter ${ }^{4}$, München 1986.

Litewsкi W., Rzymskie prawo prywatne ${ }^{5}$, Warszawa 2003.

Manigk A., s.v. 'Societas', [w:] «RE» 3/1927, szp. 774.

Merle P., Droit commercial. Sociétés commerciales ${ }^{3}$, Paris 1992.

Møller Jensen B., 'Societas leonina' or the lion's share. An analysis of Aesopica 149, Phaedrus I.5 and Babrius I.67, http.hprints.org/hprints-004-75199 (dostęp 14 grudnia 2020 r.).

Müller-Gugenberger CH., Bemerkungen zur 'societas leonina'. Fabel-haftes im Gesellschaftsrecht, [w:] Gesetzgebungstheorie, Juristische Logik, Zivil- und Prozeßrecht. Gedächtnisschrift für Jürgen Rödig, red. U. KLUG, Berlin-Heidelberg-New York 1978.

Oeuvres de R.-J. Pothier, contenant les traités du droit français, nouvelle édition, red. M. Dupin Ainé, II, Bruxelles 1831.

Oswaldus Hiligerius, Donellus enucleatus sive commentarii Hugonis Donelli de jure civili in compendium ita redacti ut verum nucleum contineat, jurisque artem, quae amplo verborum cortice in illis tecta, apertius exhibeant, Jenae 1611.

PAlmirski T., 'Societas leonina' w pogladach francuskich przedstawicieli tak zwanej eleganckiej jurysprudencji, [w:] 'Semper fidelis'. Prace dedykowane pamięci Profesora Janusza Sondla, legendzie krakowskiego fakultetu prawniczego, red. 
D. Malec, Ł. Marzec, T. Palmirski, Kraków 2017, s. 289-295 (= «Miscelanea Historico-Iuridica»17.2/2018, s. 175-188).

Palmirski T., 'Societas leonina' w twórczości glosatorów, [w:] 'Regnare, Gubernare, Administrare’. $Z$ dziejów administracji, sadownictwa i nauki prawa. Prace dedykowane Profesorowi Jerzemu Malcowi z okazji 40-lecia pracy naukowej, red. S. Grodziski, A. Dziadzio, Kraków 2012, s. 181-189.

Palmirski T., The 'Societas leonina' in the Work of Commentators, "Zeszyty Prawnicze» 18.4/2018, s. 247-258.

Poggi A., Il contratto di società in diritto romano classico, Roma 1972.

Ripert G., Boulanger J., Traité de Droit Civil d'apres le Traité de Planiol, III: Suretés réelles. Publicité fonciéere, Contrats civils. Principaux Contrats, Paris 1958.

Ripert G., Roblot R., René M., Traité de droit commercial ${ }^{16}$, Paris 1996.

Schulz F., Classical Roman Law, Oxford 1951.

SEILER H.H., Utile per inutile non vitiatur. Zur Teilungwirksamkeit von Rechtsgeschäften im römischen Recht, [w:] Festschrift für Max Kaser zum 70. Geburstag, red. D. Medicus, H.H. Seiler, München 1976, s. 127-147.

Soнм R., Institutionen. Geschichte und System des römischen Privatrechts ${ }^{17}$, opr. L. Mitteis, L. Wenger, München-Leipzig 1923.

SójKa-Zielińska K., Kodeks Napoleona. Historia i współczesność ${ }^{2}$, Warszawa 2008. SójKA-ZIElı́́sKa K., Wielkie kodyfikacje cywilne. Historia i współczesność, Warszawa 2009, s. 175-258.

Steier A., s.v. Löwe, [w:] Paulys Real-Encyclopädie der classischen Altertumswissenschaft, neue Bearbeitung begonnen von Georg Wissowa, XIII, Stuttgart 1926, szp. 985.

Stintzing R. von, Geschichte der deutschen Rechtswissenschaft, II. 2: Hälfte des 17. Jahrhunderts, München-Leipzig 1884 (przedruk Aalen 1978).

Summa Azonis locuples iuris civilis thesaurus, Venetia 1566.

ŚwięCICKA-WystrychowsKa P., Kodeks Napoleona a prawo rzymskie, «Kwartalnik Prawa Prywatnego» 13.4/2004, s. 1095-1132.

Talamanca M., Società in generale: Diritto romano, «ED» 42/1990.

WACKe A., Plaudereien über den Löwen und seine Gesellschaft, «Rechtshistorisches Journal» 10/1991, s. 117-142.

WieACKer F., Privatrechtsgeschichte der Neuzeit unter besonderer Berücksichtigung der deutschen Entwicklung ${ }^{2}$, Göttingen 1967.

Wirth R., Oswald Hilliger - ein Jenaer Professorenleben, «Mitteilungen des Freiberger Altertumsvereins» 77/1996, s. 65-81.

WoŁodkiewicz W., ZabŁocka M., Prawo rzymskie. Instytucje ${ }^{4}$, Warszawa 2005. Zimmermann R., The Law of Obligations: Roman Fundations of the Civilian Tradition, Cape Town-Wetton-Johannesburg 1990. 